\title{
A study on the state of conservation of the Roman Necropolis of Carmona (Sevilla, Spain)
}

\author{
Sergio Sanchez-Moral ${ }^{\mathrm{a}, *}$, Juan Carlos Cañaveras ${ }^{\mathrm{b}}$, David Benavente ${ }^{\mathrm{b}}$, \\ Angel Fernandez-Cortes ${ }^{c}$, Soledad Cuezva ${ }^{c}$, Javier Elez ${ }^{\mathrm{d}}$, Valme Jurado ${ }^{\mathrm{e}}$, \\ Miguel Angel Rogerio-Candelera ${ }^{\mathrm{e}}$, Cesareo Saiz-Jimenez ${ }^{\mathrm{e}, *}$

\footnotetext{
a Museo Nacional de Ciencias Naturales, MNCN-CSIC, 28006 Madrid, Spain

b Departamento de Ciencias de la Tierra y del Medio Ambiente, Universidad de Alicante, 03080 Alicante, Spain

c Departamento de Biologia y Geologia, Universidad de Almeria, 04120 Almeria, Spain

${ }^{d}$ Departamento de Paleontologia, Universidad Complutense, 28040 Madrid, Spain

e Instituto de Recursos Naturales y Agrobiologia, IRNAS-CSIC, 41012 Sevilla, Spain
}

\section{A R T I C L E I N F O}

\section{Article history:}

Received $1^{\text {st }}$ November 2017

Accepted $1^{\text {st }}$ February 2018

Available online $\mathrm{xxx}$

\section{Dedicated to Mrs. Elisa Pinilla on the} occasion of her retirement.

\section{Keywords:}

Roman Necropolis

Weathering

Deterioration

Biological colonization

Calcarenite

Mortars

Stuccos

\begin{abstract}
A B S T R A C T
The Roman Necropolis of Carmona (Sevilla, Spain) has experienced a severe deterioration since the accidental discovery in 1868 and subsequent archaeological excavations starting in 1882 . To this deterioration contributed the location in a soft calcarenite rock quarry, the adverse environmental conditions and the numerous and extensive wrong archaeological and managing interventions along more than a century. The cultural, artistic and religious importance of this Necropolis converts the protection and conservation of this archaeological site in a major issue. This work present the data obtained in a multidisciplinary research were geology, geomorphology, micro-environmental and climatic monitoring, rock petrophysical characterization, description of weathering forms and biological colonization were considered in order to propose corrective measures to minimize deterioration.
\end{abstract}

(C) 2018 Published by Elsevier Masson SAS.

\section{Introduction}

The Roman Necropolis of Carmona (Seville, Spain) represents one of the most significant burial sites in Southern Spain used during the first and second centuries A.D. At the time of its use, cremation predominated over the ritual of burial and therefore the Necropolis consists mainly of underground family tombs with one or several chambers that contain niches holding the funerary urns.

The discovery of the Necropolis occurred between 1868 and 1869 , due to the flattening works of a road. At first the Necropolis underwent excavations without control by antiquarians and collectors. With the creation of the Archaeological Society of Carmona the excavations were systematized, and the construction of a pathway around the tombs in 1885 and the Museum of the Necropolis (opened in 1887) favoured the visits. In 1930, the Necropolis became a national property and declared national monument. In

\footnotetext{
* Corresponding authors.

E-mail addresses: ssmilk@mncn.csic.es (S. Sanchez-Moral), saiz@irnase.csic.es (C. Saiz-Jimenez).
}

the last years the number of visitors ranged between 30,000 and 40,000 people-year [1].

The Necropolis was carved in a highly porous calcarenite sequence located in an ancient Roman quarry, which is easily weathered and affected by processes of micro-karstification. Weathering processes in the tombs include powdering of the rock surface and destruction of the painted walls due to condensation, evaporation and salt crystallization, processes occurring on the rock and mortar surfaces. The seepage of rain water and/or irrigation favoured the existence of damp vertical surfaces in the tombs, which were readily colonized by bacteria, cyanobacteria, algae, fungi, and in the extreme cases by bryophytes and ferns. A few reports on the biological deterioration of some tombs have been published [2-7] and comparatively less data are available on the mineralogy and weathering of the calcarenite rock $[8,9]$.

In this work an overview on the deterioration problems of the Roman Necropolis of Carmona is presented with a particular focus on four representative tombs aiming to disclose the weathering processes conducting to the severe present-day deterioration of this Necropolis and the proposal of corrective measures. 


\section{Material and methods}

\subsection{Site description}

The Necropolis of Carmona comprises a large number of tombs (about 600) carved in a 30 m-thick Neogene sedimentary sequence. Most tombs were collective mausoleums consisting of an underground chamber accessed by a shaft or stairway. The main chamber is usually rectangular, with a bench running along the walls, where the offerings were placed on open niches.

The research was carried out in a series of nine tombs of which four were selected (Four Columns, Three Gates, Garlands and 118) as case studies because they cover practically all the archaeological site in space, orientation, degree of conservation and architectural typology. Two more tombs (Postumius and Circular Mausoleum) were previously studied $[8,9]$.

\subsection{Micro-environmental and climatic monitoring system}

The monitoring station inside the tombs consists of HOBO Pro v2 data logger with built-in temperature and relative humidity sensors. A set of special sensors were installed for the narrow range of measurements expected. Air temperature was measured with an accuracy of $\pm 0.2^{\circ} \mathrm{C}$, over a range from $0{ }^{\circ} \mathrm{C}$ to $50^{\circ} \mathrm{C}$, with a resolution of $0.02{ }^{\circ} \mathrm{C}$ at $25^{\circ} \mathrm{C}$. The relative humidity sensor operated over a $\mathrm{RH}$ range from 0 to $100 \%$ with an accuracy of $\pm 2.5 \%$ from 10 to $90 \%$ typical, to a maximum of $\pm 3.5 \%$ (above $95 \%$ ), and a resolution of $0.03 \%$. Tomb air $\mathrm{CO}_{2}$ concentration was measured using a Telaire 7001 monitor. The rock-surface temperature was measured using a thermocoupled sensor TMC20-HD (Onset Computer Corporation) inserted up to $2 \mathrm{~cm}$ inside the tomb's walls, with an accuracy of $\pm 0.25^{\circ}$ at $20^{\circ} \mathrm{C}$, over a range from $-40^{\circ} \mathrm{C}$ to $50^{\circ} \mathrm{C}$ and resolution of $0.03^{\circ}$ at $20^{\circ} \mathrm{C}$.

The outdoor weather station (HOBO Weather Station) includes a tipping-bucket rain gauge (S-RGB model) for rainfall measurements. The atmospheric pressure was measured by a barometer S-BPA-CM10, providing average barometric pressure for each logging interval over the range of 660 to 1070 mbar. Finally, a 12-bit Smart Sensor (S-THB model from Onset Computer Corporation) measured the relative humidity and air temperature over a range from $-40^{\circ} \mathrm{C}$ to $75^{\circ} \mathrm{C}$ and $0-100 \% \mathrm{RH}$, with a resolution of $0.02^{\circ} \mathrm{C}$ and $0.1 \% \mathrm{RH}$ at $25^{\circ} \mathrm{C}$. A periodic calibration (in situ) of the climatic sensors was carried out.

The period of climatic monitoring, inside and outside the tombs, extended from June 2007 to April 2009. A more detailed description of the methodology on characterization of materials and microenvironmental monitoring was published elsewhere [8,9].

\subsection{Materials characterization and deterioration products}

Detailed and comprehensive in situ visual analyses were performed before the sampling campaigns of building materials (host rock, mortars and stuccos) and deterioration products (crusts, saline efflorescences and microbial colonizations). To assess deterioration phenomena, the tombs were studied at the mesoscale by means of in situ description of weathering forms. Mapping of weathering forms were performed to register and assess the state of conservation on selected areas of the tombs. ICOMOS-ICS glossary [10] was used for weathering form terminology.

The fieldwork and environmental monitoring generated a large amount and high diversity of data and, consequently, a GIS based integration was needed for better understanding of the complex interrelationships of the water cycle in the Necropolis area. The Arcgis 9.8 software was used to integrate and analyze in a GIS environment the diverse results and to obtain the land-uses models.
Qualitative, quantitative and micro-textural XRD analyses of mortars, rock samples and deterioration products were performed using XPOWDER software which allows a full duplex control of the Philips PW-1710/00 diffractometer [8,9]. Petrographic data are based on the examination of stained thin-sections by means of polarized-light microscopy.

A detailed study of the pore structure of host rock, mortars and stuccos was described in terms of porosity, pore size distribution and specific surface area (SSA), while characterization was carried out using mercury intrusion porosimetry (MIP), nitrogen and water absorption techniques and helium pycnometer.

Rock strength was estimated using P-wave propagation

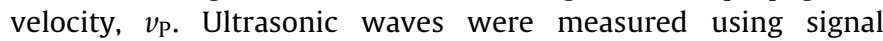
emitting-receiving equipment (Panametrics-NDT 5058PR) and an oscilloscope (TDS 3012B-Tektronix). P-wave propagation velocity was obtained with different P-polarized transducers range from $54 \mathrm{kHz}$ to $1 \mathrm{MHz}$, according to the deterioration state of the material and its roughness. The configurations of transducers pairs (transmitter-receiver) were direct (through), indirect (surface) and semi-direct (edge) transmission. The most used method was the indirect transmission, which was employed in both host rocks and mortars. The application of direct and semi-direct methods was limited to columns and some accessible ornaments such as niches carved on the walls and arches. The indirect method was also used to estimate the thickness of the stuccos and their adherence to the stone. We calibrated the method by the measurement of the thinness of the stucco when visible.

\subsection{Microbiological study}

The identification of the cyanobacteria and algae was achieved following the morphological characteristics of the taxa in field samples as well as in enrichment cultures and, if obtained, in axenic cyanobacterial and algal strains. In the last case the samples were inoculated on Petri plates containing solid BG11 culture medium. Cultures were incubated at $20^{\circ} \mathrm{C}$ and features of individual species were observed using light microscopy equipped with a photographic camera. Taxonomic identification was based on morphological characters of colonies growing on the agar plates using identification keys [11-14]. Bacteria and fungi were not studied in this work, but comprehensive data on the microbial communities in representative tombs can be found elsewhere [2-9].

Most lichens were identified directly in the tombs, although some samples were collected and studied in the laboratory. Species were identified or confirmed following lichen identification keys [15-17].

\section{Results}

\subsection{Geology of the Necropolis of Carmona}

The host rock of the Necropolis consists of about $30 \mathrm{~m}$-thick succession of Neogene yellowish-brown calcarenite beds, corresponding to the Calcarenite of Carmona or Alcor Formation (Fig. 1). These decimetric thick calcarenite beds contain a large abundance of silicate grains (mainly quartz) and fragments of fossils (mainly molluscs) and are separated by centimetric layers of sandy lutites (Fig. 2). This carbonate succession is organized into four sections or sequences, which in turn are divided into seven sub-sequences, corresponding to the lithological units used for the design of the geological mapping of the Necropolis (Fig. 1). All the calcarenite sequences show fining and thinning-upward trends, from 1-2 m thick beds at the base to decimeter-thick beds at the top.

Carmona calcarenites are coarse-grained (coarse sand to microconglomerate) showing a grain-supported texture with moderate 

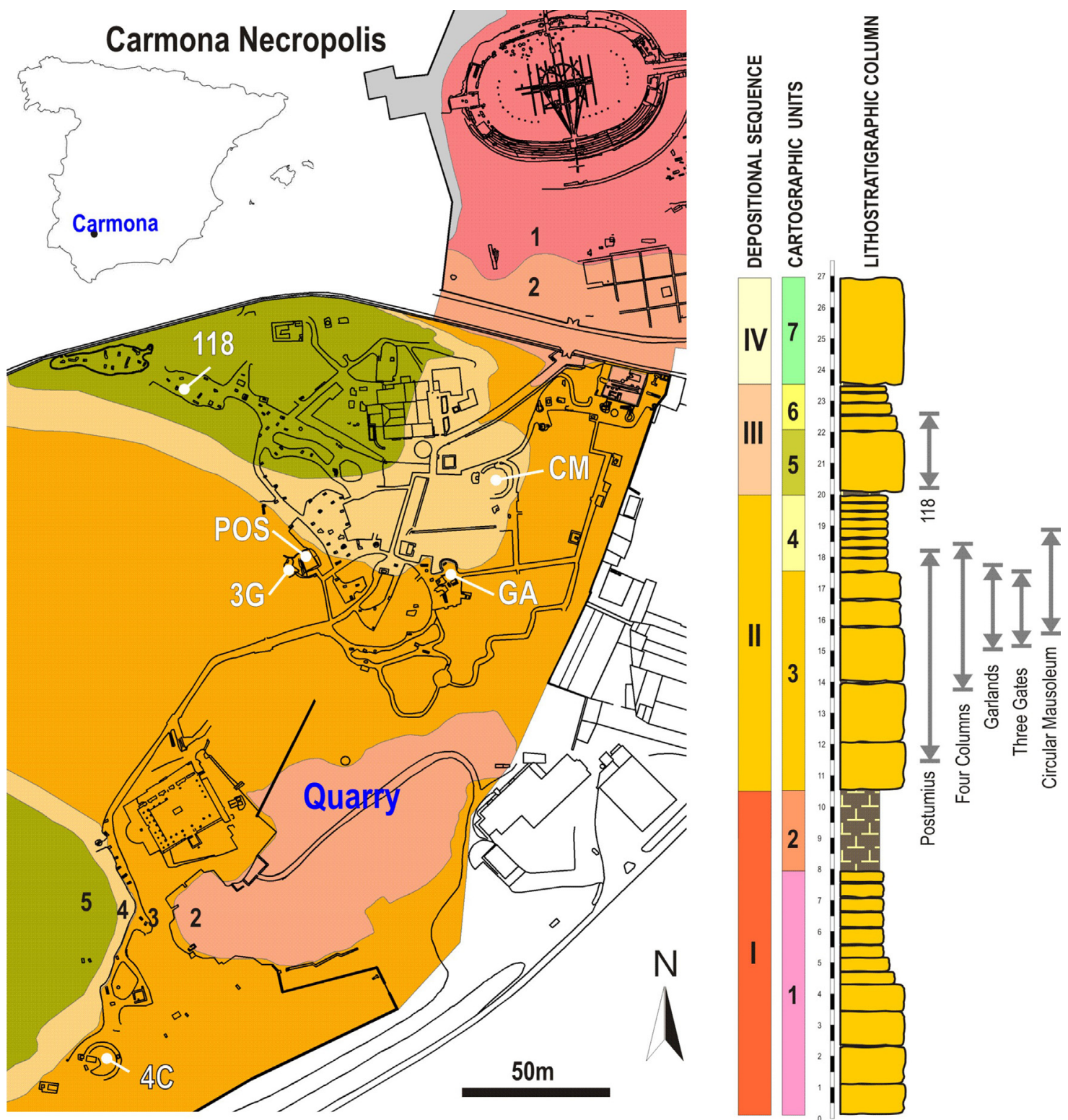

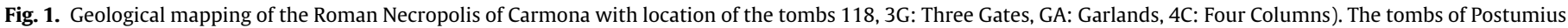

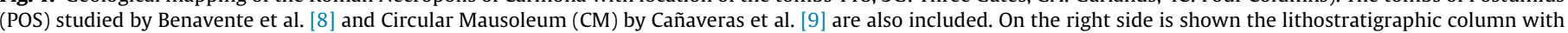
indication of the cartographic units and location of the tombs.
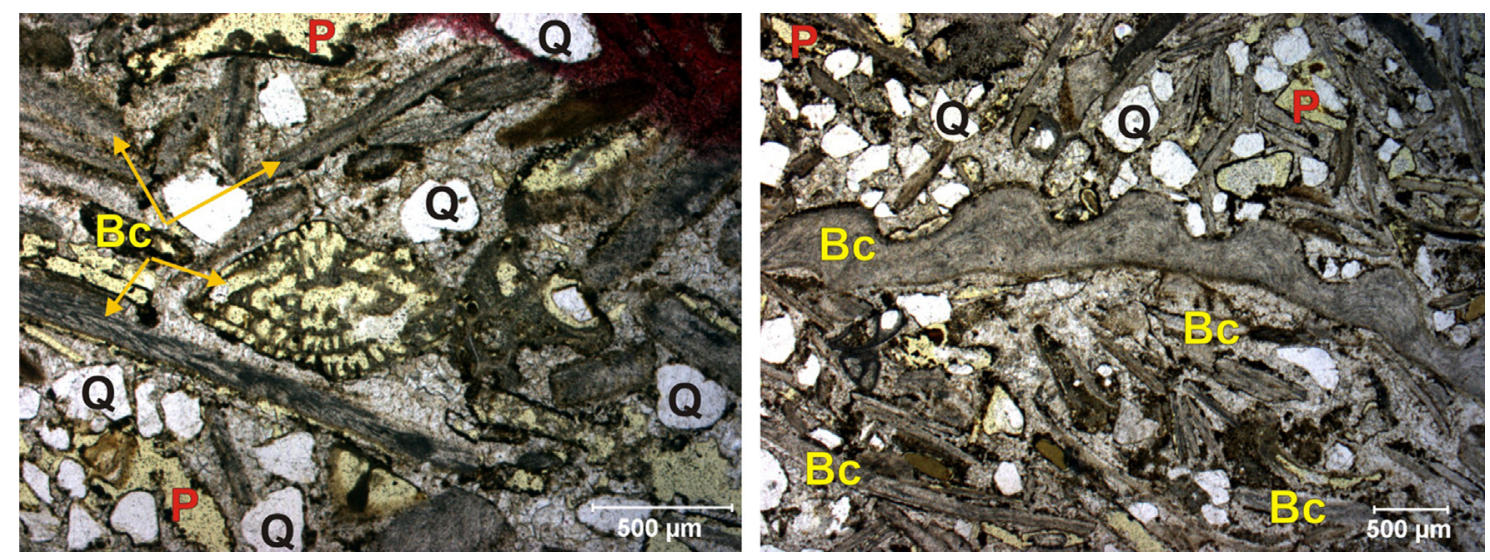

Fig. 2. Petrographic thin section of Carmona calcarenite showing abundant bioclasts (Bc) and siliciclastic grains (mainly quartz, Q). High porosity (P) is also observed. 
to poor sorting. Two main types of grains predominate (Fig. 2): (i) Bioclasts (50-80\%), mainly reworked fragments of molluscs, and variable content of foraminifera, echinidae, algae, bryozoa, etc. Many of the mollusc fragments and the foraminifera are micritized and/or recrystallized. (ii) Extraclasts, consisting mainly of siliciclastic (terrigenous) grains, predominantly monocrystalline quartz, although polycrystalline quartz, chert and feldspar are also recognized. Glauconite, micritic intraclasts and fragments of oolites are minor framework grains. The matrix is micritic with a variable content of clays. Cements are mainly calcitic, although ferruginous cement has also been observed.

The size and nature of grains, the small amount of matrix and interparticle cement and their nature, textural typology and distribution, all conditioned the petrophysical behaviour of materials (porous system, mechanical resistance, etc.).

\subsection{Geomorphological study}

The application of GIS techniques in the Necropolis area provides a land-use and management tools that minimize deterioration processes in excavated tombs. These models, validated with the data obtained from field work, allow the study of the morphological characteristics of the Necropolis and the tombs. The data reveal that the slopes in the Necropolis are relatively low (less than $12^{\circ}$ ) and the predominant orientations are $\mathrm{N}$ and $\mathrm{S}$. The potential insolation of the site is very high through the year with important rises from the winter solstice to the summer solstice. The spatial distribution of the insolation increases from the winter solstice to the spring equinox and from this to the summer solstice is very similar.

The extent of direct sunlight from winter to summer clearly increases. Moreover, there is a significant seasonal variation in the extent of direct sunlight in the immediate environs of the monitored tombs. Thus, the architecture and orientation of each tomb determines the amount of solar radiation that enters the interior at each year season.

The surficial drainage is strongly conditioned by recent anthropic activities related to the archaeological excavations and the construction of ornamental garden areas including paths delimited by parterres, landscaping works, small perimeter walls at the tomb entrance, wrong drainage systems, etc. that seasonally causes the flooding of the tombs. The transport of sediments associated with this drainage produces the filling and clogging of the natural and artificial drains of the Necropolis. It generates zones that act as sinks, where the water is retained and incipient soils are formed. It has also been found that in the past the existing drainage network had features that were notoriously different from the current ones. At present, runoff presents meandering morphologies and short spatial development (due to the presence of local sinkholes, tombs, walls, etc.) in the headwaters of the Necropolis Museum area, something unusual in a natural network. This is very different from the morphologies that develop in the valley to the SW of the Museum, with less anthropic influence and more similar to the paleodrainage network, where dendritic forms and longer water courses predominate. Currently, the active geological processes in the area are of low intensity.

\subsection{Petrophysical characterization of the host rocks of the tombs}

All the host rocks (calcarenite beds) of the Necropolis are very porous (20-40\%), with a wide variety in size and type of pores. Based on the distribution of pore sizes of these materials, three different types of host rocks predominate in different areas of the Necropolis (Figs. 3 and 4):

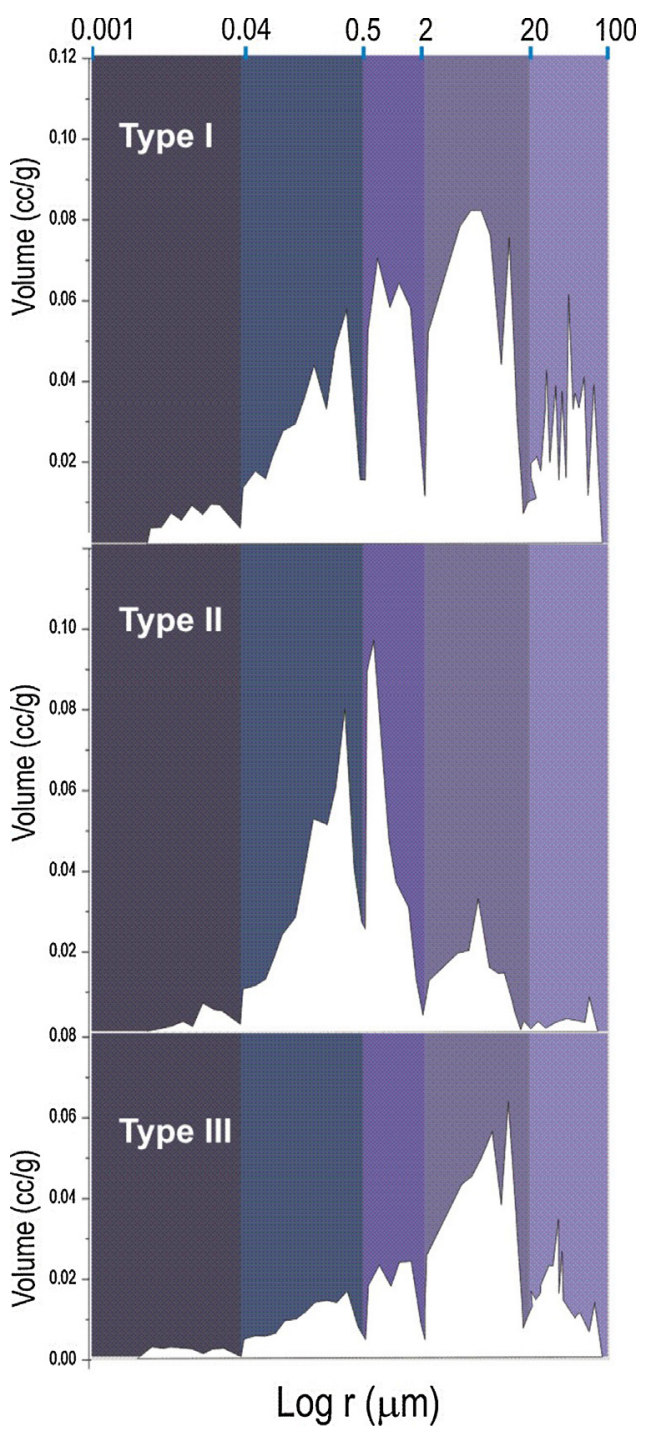

Fig. 3. Types of pore-size distribution curves of Carmona calcarenite (see text for explanation).

- Host rock with a high porosity values and pores of all sizes (Type I). Type I calcarenites yield slightly higher values of specific surface area (SSA), which is directly related to porosity and inversely related to pore size [18]. High SSA values indicate a high capacity and susceptibility to water condensation and retention within porous materials, and consequently, a high bioreceptivity [19]. These materials are present in most of the tombs (Circular Mausoleum, Garlands, Three Gates, Four Columns and Postumius) and are the most prone to be deteriorated.

- Host rocks with a high porosity values with predominance of intermediate size pores $(0.1-0.5 \mu \mathrm{m}$ and $0.5-2 \mu \mathrm{m})$ (Type II), represented by calcarenites that are active for water vapour condensation and retention as well as decayed by salt crystallization $[8,19]$. They are only represented in basal levels of the tombs of Postumius and Four Columns).

- Host rock with high porosity and predominance of large pores (2-20 $\mu \mathrm{m}$ and $20-100 \mu \mathrm{m})$ (Type III), that represent materials very appropriate for the circulation of fluids [8] (processes of dissolution and washing of fine-grained materials), but not for their retention. The tombs of Postumius and 118 are included in this type. The low clay content of these materials is evidenced by their low values of SSA. 


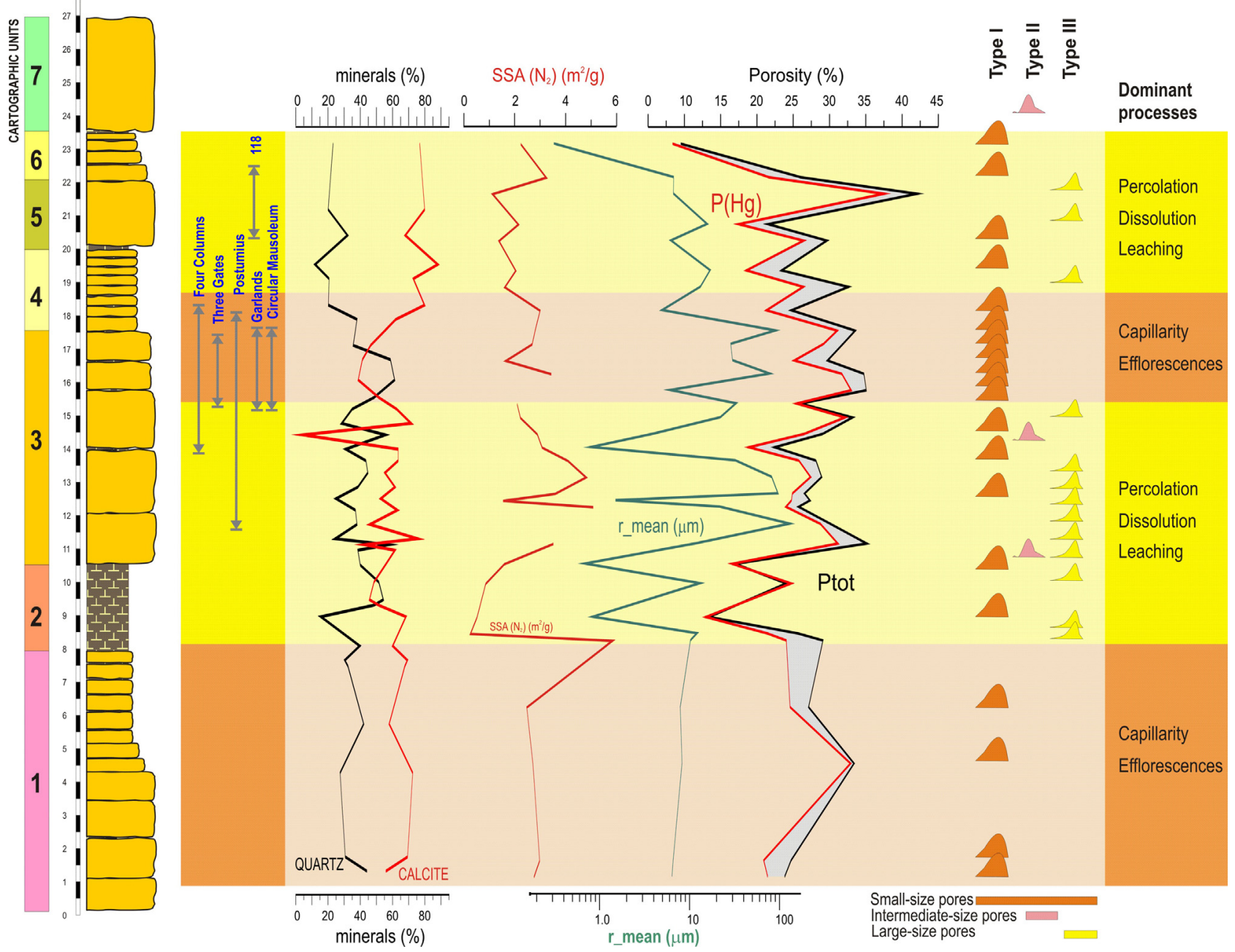

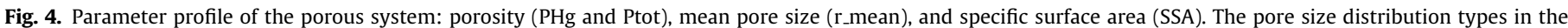
lithostratigraphic column is also indicated.

Benavente et al. [8] showed that all the host rocks have a very low resistance to simple compression $(2.95-11.79 \mathrm{MPa})$, as shown by the values of propagation velocity of the $P$ waves, $v_{P}$. The values of $v_{\mathrm{P}}$ vary between 1500 and $3000 \mathrm{~m} / \mathrm{s}$, being especially low in the more porous levels. Salt crystallization tests indicated a direct relationship between the porous system and mechanical strength. The weight loss after salt crystallization test showed that all the rocks studied had a very low durability, although the calcarenites with less durability displayed low mechanical resistance and a distribution of pores Type I.

The in situ characterization of mortars and stuccos by ultrasounds showed that the degree of conservation of the original stuccos depended not only on the nature of the stucco but also on the quality of the rock on which it was applied. $v_{\mathrm{P}}$ values of stucco ranged from 800 and $1500 \mathrm{~m} / \mathrm{s}$, whereas in the rocks were from 1100 to $5000 \mathrm{~m} / \mathrm{s}$. Those tombs that have higher $v_{\mathrm{P}}$ (higher than $4000 \mathrm{~m} / \mathrm{s}$ ) values have better preservation. Moreover, in situ $v_{\mathrm{P}}$ measurements showed than the well-conserved stuccos presented a homogenous thickness $(2-3 \mathrm{~cm})$ and a well adherence to the stone.

\subsection{Study of the external meteorological conditions and the microclimate of the Necropolis}

The external meteorological conditions have effect on the water balance of the Necropolis and directly affect the processes of dete- rioration of the outcropping host rocks. They also directly influence the microenvironmental conditions of the tombs and the deterioration processes that affect their walls and roofs.

The microclimatic study along an annual cycle in the Necropolis confirms that the pluviometric regime of the area is typical of a semi-arid climate, with sporadic rains of torrential nature (Fig. 5). This scarcity of rainfall $(<400 \mathrm{~mm} /$ year $)$, coupled with the high annual average temperature of the area (around $18^{\circ} \mathrm{C}$ ) determines high evaporation rates and causes a negative annual water balance in the Necropolis, with an average daily deficit of $4.3 \mathrm{~mm} /$ day and extreme droughts that raise it up to $11.5 \mathrm{~mm} /$ day. However, the torrential nature of rainfall causes a great impact on the conservation of the Necropolis. The excess of water and the triggering of surface runoff processes transform the tombs into active sinks that collect large amounts of water in a very short time (Fig. 6A and B). On the other hand, the water balance calculations by cartographic units also show a great spatial homogeneity due to the textural and compositional homogeneity of the calcarenites (Table 1).

The processes of effective condensation in the tombs are very active and develop over long intervals of time as a consequence of materials' pore structure (Table 2 and Fig. 6C).

The effective condensation in the tombs is more intense during the last three months of the year. It implies a great period of time with water available in the host rocks that origin the main deterioration mechanisms. Under the registered environmental conditions, effective condensation periods are short (usually less 


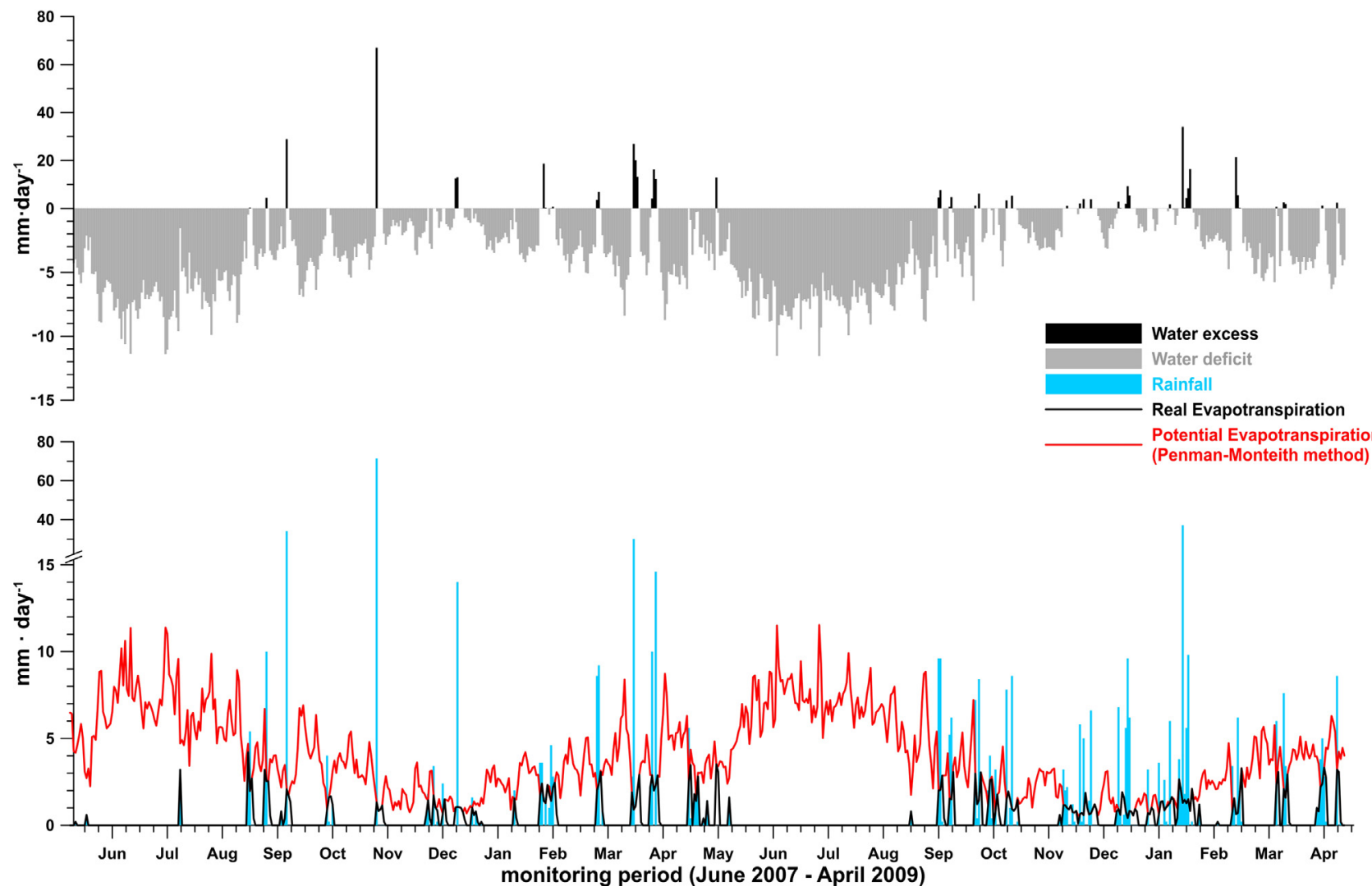

Fig. 5. Evolution of the temperature, relative air humidity and rainfall in the Carmona Necropolis during the period 2007-2009, in relation with the inter-annual climatic variations of the last decade.
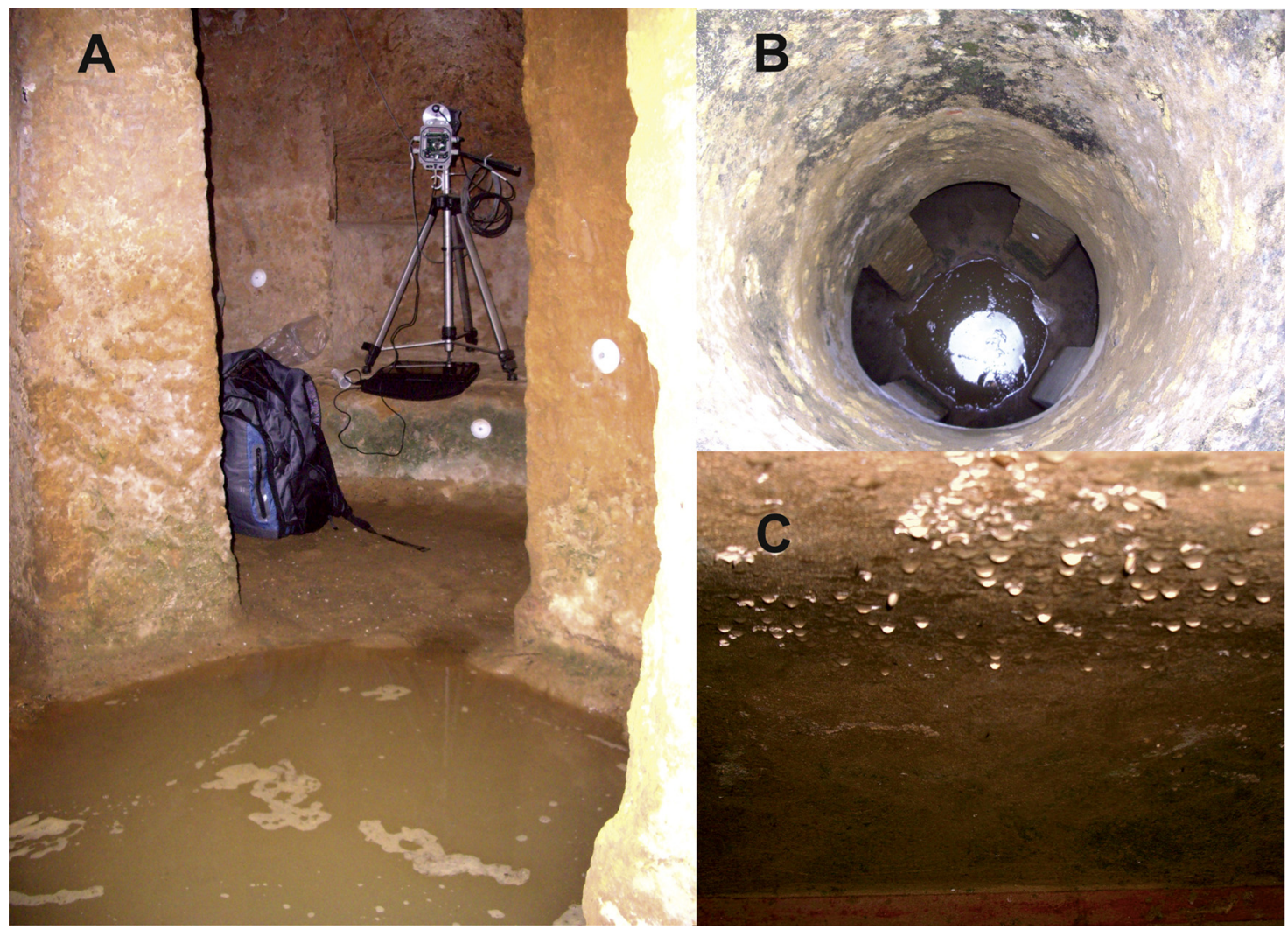

Fig. 6. Flooding and water condensation. A,B: Tomb of the Four Columns. C: Tomb 118. 
Table 1

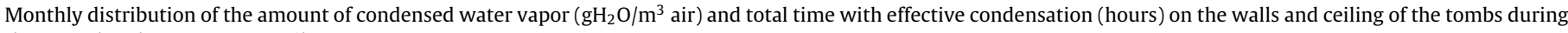
the annual cycle May 2008-April 2009.

\begin{tabular}{|c|c|c|c|c|c|c|c|c|}
\hline \multicolumn{2}{|c|}{ Year/month } & \multicolumn{7}{|c|}{ Surplus rainfall (mm) per cartographic unit } \\
\hline & & U1 & $\mathrm{U} 2$ & U3 & U4 & U5 & U6 & U7 \\
\hline \multirow[t]{4}{*}{2007} & Sep & 7.3 & 6.7 & 3.6 & 5.7 & 0.6 & 5.7 & 7.8 \\
\hline & Oct & 31.4 & 30.8 & 28.0 & 29.9 & 25.0 & 29.8 & 31.9 \\
\hline & Nov & 68.2 & 67.9 & 66.2 & 67.5 & 63.2 & 67.5 & 68.5 \\
\hline & Dec & 0.0 & 0.0 & 0.0 & 0.0 & 0.0 & 0.0 & 0.3 \\
\hline \multirow[t]{8}{*}{2008} & Jan & 26.7 & 26.4 & 24.6 & 25.9 & 21.6 & 25.9 & 27.0 \\
\hline & Feb & 22.2 & 21.6 & 18.4 & 20.7 & 15.4 & 20.6 & 22.7 \\
\hline & Mar & 11.6 & 11.3 & 9.5 & 10.8 & 6.5 & 10.8 & 11.8 \\
\hline & Apr & 95.2 & 94.6 & 91.1 & 93.7 & 85.1 & 93.7 & 95.8 \\
\hline & May & 15.3 & 14.7 & 12.0 & 13.8 & 9.0 & 13.7 & 15.9 \\
\hline & Jun & 0.0 & 0.0 & 0.0 & 0.0 & 0.0 & 0.0 & 0.0 \\
\hline & Jul & 0.0 & 0.0 & 0.0 & 0.0 & 0.0 & 0.0 & 0.0 \\
\hline & Aug & 0.0 & 0.0 & 0.0 & 0.0 & 0.0 & 0.0 & 0.0 \\
\hline \multicolumn{2}{|c|}{ Average } & 277.9 & 274.0 & 253.2 & 268.1 & 226.5 & 267.6 & 281.6 \\
\hline
\end{tabular}

Table 2

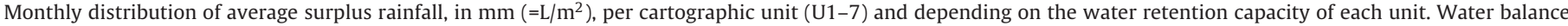
adjusted by the Penman-Monteith method [20].

\begin{tabular}{|c|c|c|c|c|c|c|c|c|c|}
\hline \multirow[t]{2}{*}{ Year } & \multirow[t]{2}{*}{ Month } & \multicolumn{2}{|c|}{ Tomb 118} & \multicolumn{2}{|c|}{ Garlands } & \multicolumn{2}{|c|}{ Three Gates } & \multicolumn{2}{|c|}{ Four Columns } \\
\hline & & $\mathrm{H}_{2} \mathrm{Ov}$ & Time & $\mathrm{H}_{2} \mathrm{Ov}$ & Time & $\mathrm{H}_{2} \mathrm{Ov}$ & Time & $\mathrm{H}_{2} \mathrm{Ov}$ & Time \\
\hline \multirow[t]{8}{*}{2008} & May & 1065 & 345 & 281 & 165 & 1504 & 567 & 1739 & 564 \\
\hline & June & 299 & 123 & 1 & 1 & 80 & 67 & 937 & 383 \\
\hline & July & 14 & 1 & 0 & 0 & 0 & 0 & 2 & 5 \\
\hline & August & 0 & 0 & 0 & 0 & 0 & 0 & 0 & 0 \\
\hline & September & 44 & 16 & 38 & 16 & 16 & 10 & 59 & 39 \\
\hline & October & 239 & 146 & 367 & 213 & 358 & 226 & 541 & 250 \\
\hline & November & 5 & 10 & 124 & 90 & 49 & 54 & 77 & 66 \\
\hline & December & 539 & 194 & 1491 & 436 & 1281 & 403 & 1284 & 371 \\
\hline \multirow[t]{4}{*}{2009} & January & 1194 & 350 & 2042 & 513 & 1512 & 486 & 1648 & 457 \\
\hline & February & 849 & 357 & 1387 & 490 & 1779 & 545 & 1542 & 495 \\
\hline & March & 1182 & 341 & 1180 & 401 & 1700 & 506 & 1715 & 479 \\
\hline & April & 0 & 0 & 181 & 122 & 585 & 296 & 868 & 374 \\
\hline \multicolumn{2}{|c|}{ Total annual } & 5430 & 1881 & 7092 & 2444 & 8863 & 3158 & 10,411 & 3482 \\
\hline
\end{tabular}

than one day), which determine that condensation and evaporation cycles in the tombs also follow short periods. This implies a situation of high water stress with continuous wetting-drying processes that the tombs did not suffer before their discovery, and that causes the development of different deterioration mechanisms.

\subsection{Deterioration of the building materials of the Necropolis: forms, processes and mechanisms}

The types of deterioration of the building materials are very different. In order to synthesize and set the deterioration types according to their typology and the decaying agents, they have been grouped into three main categories: surface deposits, loss of materials and biological colonizations. Selected examples of the described pathologies are represented in Table 3.

\subsubsection{Surface deposits}

In all the tombs studied, even in the recently restored ones, there are abundant patinas and superficial deposits of dust and other microparticles. They cause an aesthetical variation of the original colour/brightness of the mortars and stuccos, but that do not produce important changes in the cohesion and durability of the host rocks. In this study we have focused especially on the superficial deposits that do cause important changes of the substrata, distinguishing two main types.

3.5.1.1. Crusts/encrustations. They represent a layer of coherent material of different thickness $(0.2-2 \mathrm{~mm})$ of calcitic composition
$\left(\mathrm{CaCO}_{3}\right)$ and from a textural point of view have two predominant typologies: Botryoidal (crystalline aggregates in grape-like forms) and smooth (crystalline aggregates displaying flat surfaces) (Table 3). They are not very extensive in the tombs and, in general, are scattered in walls with preferential condensation, where in most cases are associated with the development of microbial colonizations.

3.5.1.2. Efflorescences. The saline efflorescences are very abundant in the tombs and consist mainly of whitish, powdery or whisker-like crystals of gypsum $\left(\mathrm{CaSO}_{4} \cdot 2 \mathrm{H}_{2} \mathrm{O}\right)$ and, to a lesser extent, halite $(\mathrm{NaCl})$ and thenardite $\left(\mathrm{Na}_{2} \mathrm{SO}_{4}\right)$ (Table 3). Its presence occurs massively, especially in favour of the porous system of the rock, in hollows (by dissolution or fragmentation of the substratum) that expose rough mortars and also in the contact between restoration mortars and host rock. In the case of surface stuccos, there are accumulations of fibrous gypsum crystals that come from the micro-dissolution of the original substratum and its re-precipitation on the surface is a consequence of the successive condensation/evaporation cycles.

Surficial modifications such as efflorescences or simple accumulation of dust, microorganisms, etc., produce non-cohesive surface deposits in all the tombs with different intensity. There is a greater variability in textural types in the deposits of tombs that preserve mortars/stuccos, such as Circular Mausoleum, Three Gates or 118 tombs. Also, the density and compositional variability of efflorescences, mainly gypsum $\left(\mathrm{CaSO}_{4} \cdot 2 \mathrm{H}_{2} \mathrm{O}\right)$, thenardite $\left(\mathrm{Na}_{2} \mathrm{SO}_{4}\right)$ and halite $(\mathrm{NaCl})$, is more important in tombs with recent restorations 
Table 3

Examples of the main deterioration types observed in the Necropolis tombs.

\begin{tabular}{ll}
\hline Surface deposits & Loss of material
\end{tabular}

Biological colonization

Crusts

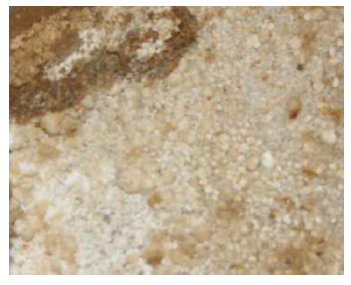

Globulitic

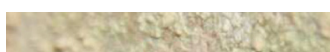

Void

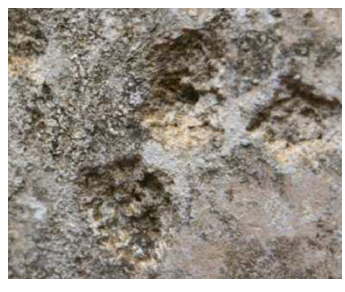

200.

ototrophic

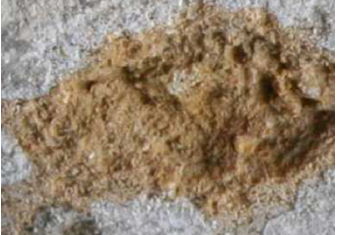

microorganisms

Cyanobacteria

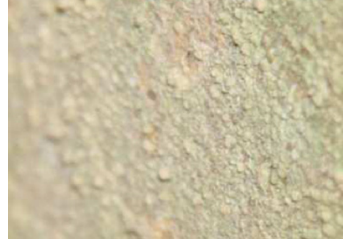

Smooth

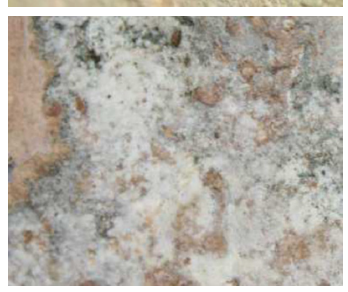

Sanding

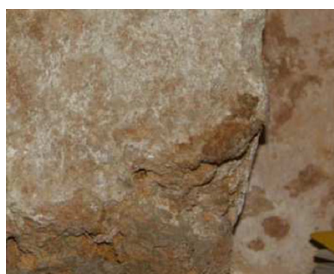

Algae

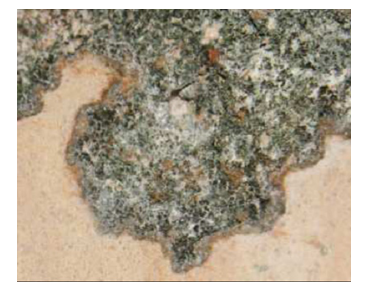

Efflorescences

Massive

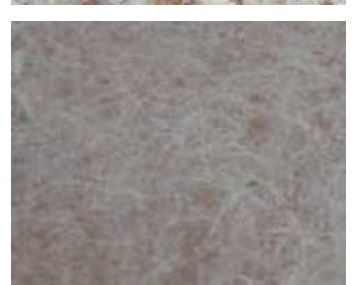

Crack

Old Streptomyces colonies

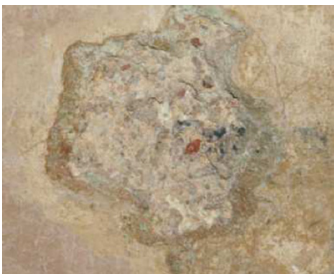

Lichens

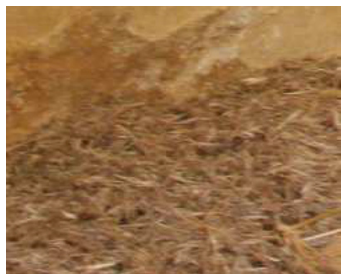

Detachment

Scaling

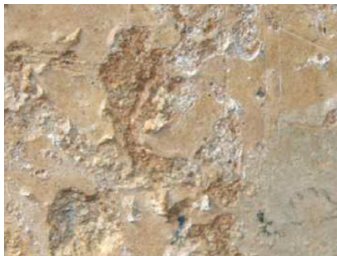

Streptomyces colonies
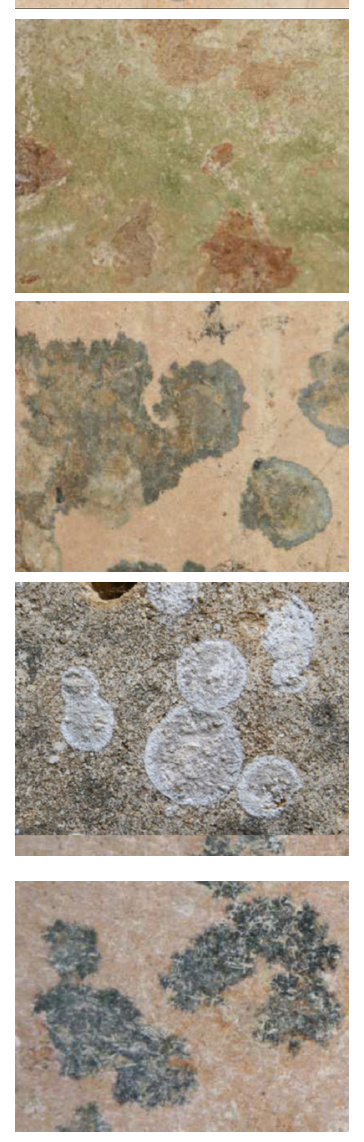
such as Postumius [8], where the degree of rock disintegration is severe.

\subsubsection{Loss of material}

The loss of the original material from the tombs is the worst and most widespread form of deterioration in the tombs. The processes and agents responsible for this loss are diverse. In this study it has been grouped in two categories.

3.5.2.1. Disintegration, sanding, dissolution. Most of these pathologies are related to the loss of cohesion of the substratum, either by the dissolution of textural elements (matrix and cement), which are part of the calcarenites and also of mortars, and/or by the mechanical action of the salt crystallization within the porous system. Locally, small-scale surface deformations associated with these processes are observed, either as blistering or bursting. Losses of materials due to anthropic actions, such as graffitis and scratches, were present in most tombs open to the public [9]. These aggressions lead to an increase in the exposure of the surface materials and a consequent increase in their capacity of water retention, favouring the colonization of microbial communities, which is very patent in the Circular Mausoleum [7].

These processes are enhanced by the special microenvironmental conditions of the tombs, characterized by high humidity levels and by the successive condensation/evaporation cycles that favour chemical dissolution and the formation of saline efflorescences. With time, the materials resulting from this deterioration accumulates in niches and grounds, in the latter case it diminishes the porosity of the tomb ground and in case of floodings allows its ponding.

3.5.2.2. Cracks, detachments and collapses. Sometimes the material losses observed in the tombs represent a greater separation of a part of the host rock, either perpendicular (cracks) or in parallel (detachments and collapses) to the surface (Table 3). Both processes are very common in the tombs and are favoured by the superposition of materials with different compositional, textural and petrophysical characteristics (stuccos, mortars, calcarenite).

The factors and mechanisms of deterioration involved in these pathologies are very diverse with a prominent role of water in the preferential dissolution in lines of weakness (cracks, contact surfaces between building/restoration materials), in weight gain and mechanical gravitational instability and in the action of the salts.

The collapses generally affect the roof of many tombs, especially when the roof is located closer to the surface and has a smaller thickness of rock. In these cases, the thermal stress caused by cycles of a strong heating of the rock during the day and a later cooling in the night can become an important factor in the roofs collapses. These results in differential expansion-contraction cycles of the different roof materials (rock-mortar-stucco) and it can be intensified by repeated events of rainfall and dissolution of saline phases.

In summary, the processes of material loss (disintegration) suffered by substrata are also widespread throughout the site and are one of the most important pathologies suffered by the tombs. Only in tombs with a good state of preservation, like the 118 , these processes are not abundant. The loss of cohesion between the grains of the calcarenite is produced by mechanisms of salt crystallization, by the dissolution of the orthochemical elements (cements), or by the interaction of both processes.

\subsubsection{Biological colonizations}

The presence of microbial colonizations covering rocks, mortars and stuccos is common in the tombs (Table 3). The most frequent indicators of biodeterioration among the multiple types observed in the Necropolis are:
- Green stains or mats, sometimes covering wide areas, due to the development of phototrophic microorganisms. These stains or mats remain green while the microorganisms are active. When desiccation occurs, for example by intense direct sunlight or dryness periods, the mats turned dark to black and its association with saline efflorescence or other surface deposits is very common. The calcarenite outcrops and tomb entrances are covered by an abundant lichenic community, the most common lichens include Caloplaca spp., Lepraria spp., Squamarina spp., Toninia spp. and Verrucaria spp. Cyanobacteria and algae are abundant in the interior of the tombs, namely Scytonema julianum, Geitleria calcarea, Loriellopsis cavernicola, Phormidium sp., Chroococcidiopsis sp., Synechococcus elongatus, Gloeocapsa rupestris, Chlorella vulgaris, Muriella terrestris, etc. [2,3,9,21].

- Colonizations by non-phototrophic microorganisms cause more restricted stains than the green mats; an example are the violet stains that appear inside the Circular Mausoleum which are caused by the excretion of pigments by Streptomyces $[6,7,9]$. In addition, a number of bacteria have been described in the tombs, including some novel species $[5,8,22,23]$.

The biological colonization is present in all the tombs and its distribution depends on extrinsic factors such as orientation, degree of insolation, degree of humidity, ventilation, etc., and intrinsic, such as texture (grain size, roughness, etc.) and rock composition. In this sense the high intrinsic bioreceptivity of some Roman mortars, especially those of coarse texture and calcium carbonate composition, stands out in contrast to the low bioreceptivity of most stuccos.

In areas exposed to or near the exterior, the development of a lichen cover, in some way bioprotective, as described by Ariño et al. [24], is the most common phenomenon, as can be seen all over the Necropolis. In wet, protected areas and with intermittent water circulation, (e.g. Four Columns, Garlands), it is common the development of complex biofilms or mats of cyanobacteria, algae, mosses (Fossombronia sp., Fissidens bryoides, Targionia hypophylla, Timmia bavarica), as well as the presence of higher plants (Umbilicus rupestris) and animals (insects, gastropods, etc.). In this last aspect the physico-mechanical deterioration of the zones of perching or dwelling of birds, stand out.

In the interior of the tombs phototrophic microorganisms develop preferably in deteriorated (detachments, sanding areas, etc.) and wet zones (close to the ground by capillarity after flooding). This is observed notably in the Garlands, Four Columns and 118 tombs.

\section{Case studies}

\subsection{Tomb 118}

It is a small tomb, with $3 \mathrm{~m}$ of vertical development (2-2.2 m in the interior chamber) (Fig. 7), which has a slope entrance with stairs, oriented S-SW $\left(\mathrm{N} 199^{\circ} \mathrm{E}\right)$ and that, at certain periods of the year, suffers direct and intense insolation. The tomb was carved in the Depositional Sequence III, in the massive metric-thick beds of the upper part of Unit 5 and the lower beds of Unit 6 that constitute the roof of the tomb (Fig. 7).

The interior has a rock cover of $1.2-1.5 \mathrm{~m}$, and presents poorly developed soil patches. Regarding climatic conditions, their average annual temperature $\left(16.96^{\circ} \mathrm{C}\right.$ in 2008$)$ is slightly lower than the external temperature $\left(18.01^{\circ} \mathrm{C}\right.$ in 2008) and relative humidity clearly higher (mean values inside and outside of 76.2 and $62.6 \%$, respectively). The tomb is flooded by direct runoff, although there is no evidence that the water be retained for long time. Tomb 118 has low annual values of effective condensation (Table 2) compared to the rest of the studied tombs. This is consistent with a 


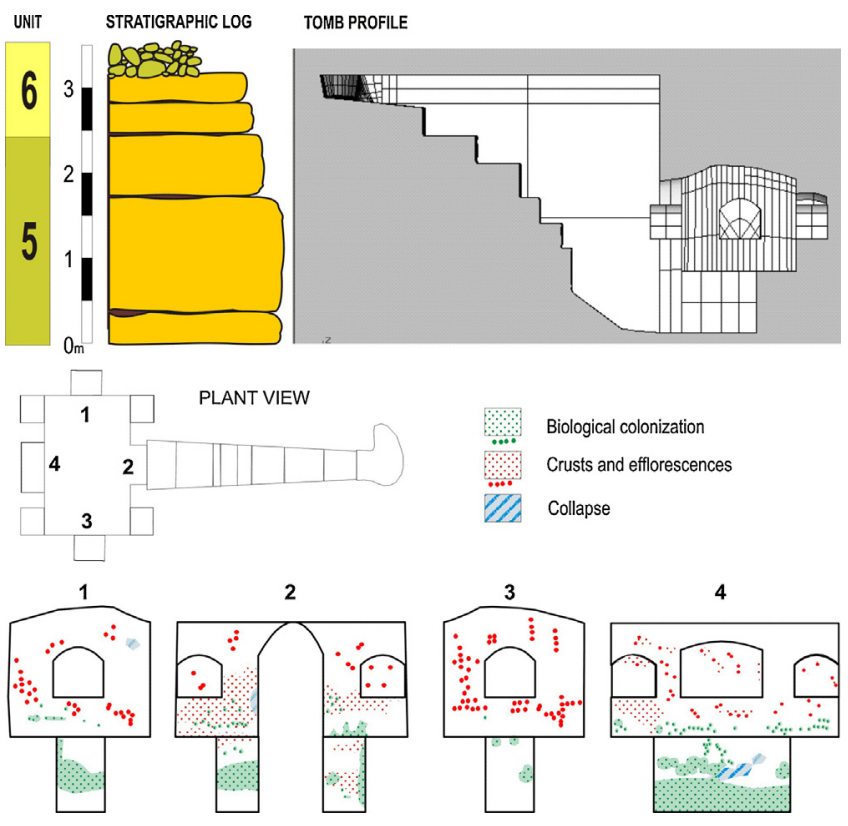

Fig. 7. Tomb 118. Lithostratigraphic column and tomb profile (top). Location of main deterioration types in the tomb walls (bottom).

relatively low degree of deterioration, in which $80-90 \%$ of original material remains in the walls and roof. It is the best preserved of all the tombs, situation already observed in a survey carried out in 1994 [21]. The tomb has not undergone major processes of fragmentation, scaling or crumbling in walls and roof. The greatest deterioration corresponds to the ground due to periodic flooding and no signs of direct percolation from the walls or roof are observed. Direct ventilation is only produced by the stairway entrance. The loss of material is restricted to some entrance edges and niches. Detachment features of lesser importance are scattered throughout the interior of the tomb (Fig. 7). Surface deposits consist mainly of efflorescences and crusts of whitish tones. The efflorescences are sulfates (gypsum and traces of thenardite) and have a powdery microcrystalline texture. They are preferably concentrated on rough substrata, such as small disintegrations. Crusts, of calcitic mineralogy, have a submillimetric thickness in most cases and have a botryoidal or microglobulitic texture. Biological colonization is quite widespread, especially in the outer zones. The access stairway is heavily colonized by algae, lichens, etc.

\subsection{Tomb of the Four Columns}

It is a restored tomb, which does not exceed $2 \mathrm{~m}$ of vertical development in the interior chambers. It has an entrance stairway oriented S (N168 ${ }^{\circ}$ and a central opening (oculus) in the main chamber, which is at a higher level than the entrance. Except for the open area of the oculus, the tomb chambers have a cover of 1.4 to $1.8 \mathrm{~m}$ of thickness of calcarenite and in the north area, in addition, from 0.6 to $0.7 \mathrm{~m}$ of parterre. The place is strongly anthropized.

The tomb was carved in the Depositional Sequence II, in the massive metric-thick beds of the top of Unit 3 and the decimetric lower beds of Unit 4 (Fig. 1). The ventilation of the tomb is controlled by the existence of a stairway entrance and an oculus at different height. This tomb also suffers flooding due to direct water rainfall through the stairway and the oculus. The water accumulates first in the lower central zone affecting the columns and then overflows (Fig. 6A and B). The phenomena of capillary ascent and biological colonization associated with periodic flooding favoured by the accumulation of fine materials (silt-clay) in the tomb ground, which remains damp even in summer months, are apparent. In addition,

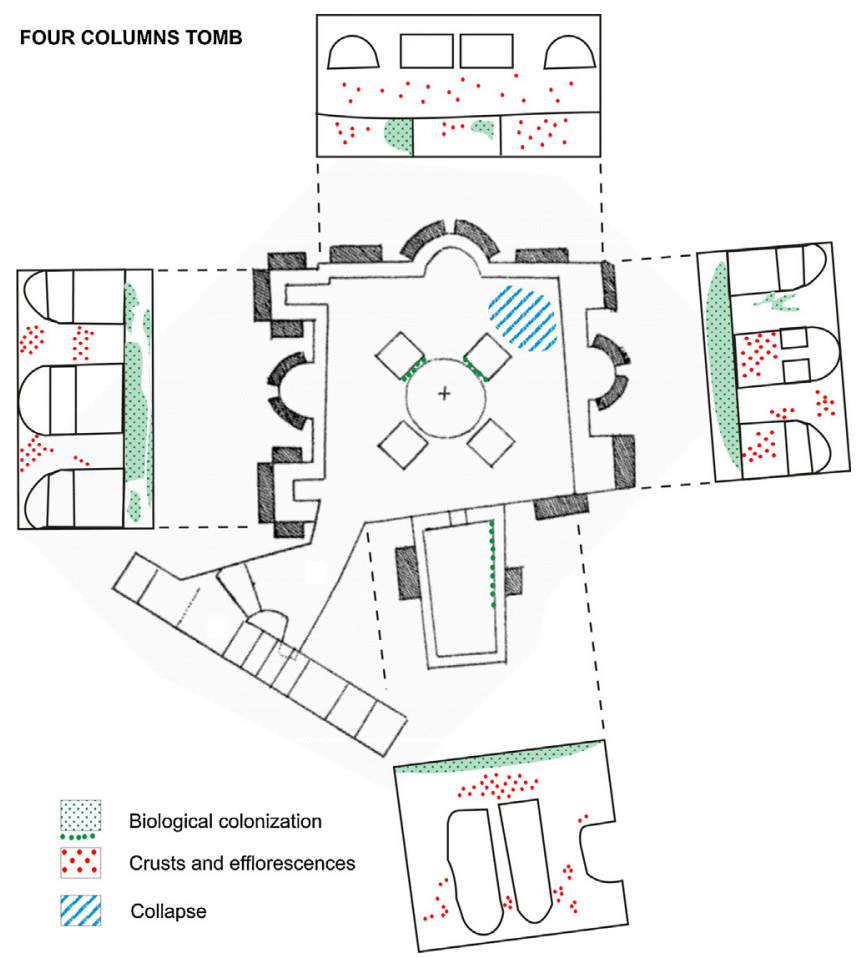

Fig. 8. Tomb of the Four Columns. Location of main deterioration types in the tomb walls and roof.

in this tomb stands out its low temperature, high relative humidity and very high annual levels of condensation (Table 2).

This tomb presents a severe deterioration, with important material losses by partial collapse of the roof. The deterioration indicators are varied and abundant: detachments, loss of material (alveolization, granular disintegration), surface deposits and biological colonization (Fig. 8). The processes of granular disintegration are extended by walls and roof, both in the main chamber and the surrounding rooms. The most important surface deposits consist of efflorescences and crusts. Efflorescences are white, fine and powdery and have been developed in favour of the thick mortar, especially in lower areas, but also are evident in the roof.

The mineralogy of the efflorescences is mainly gypsum, occasionally with traces of thenardite. The calcite crusts are hard, whitish, of little thickness and very widespread throughout the tomb. Biological colonization is driven by the entry of water and direct light by the oculus. Biofilms (green colonies of algae and cyanobacteria) are preferably distributed on the walls near the ground due to periodic flooding. They are arranged in a more or less continuous strip that reaches a height of up to $30 \mathrm{~cm}$ from the ground in all the walls of the quadrangular base and in the southern faces of the columns of the northeast and northwest sides. They are not seen in the roof, but appear in some niches. Lichens and other lithobionts also develop on the interior walls of the oculus. Other deterioration processes are produced by the presence of animals and their footprints: gastropods, insects, spiders.

\subsection{Tomb of the Garlands}

It is a large tomb, which does not exceed $3 \mathrm{~m}$ of vertical development ( $2 \mathrm{~m}$ in the interior chamber) (Fig. 9). It has an entrance oriented to the $\mathrm{W}\left(\mathrm{N} 267^{\circ}\right)$ and an oculus, in the centre of the main chamber, which is at the same level as the entrance (Fig. 9). This fact makes that the ventilation does not have the same pattern that in other tombs with oculus (Tomb of the Four Columns). Microclimatically this tomb is similar to 118 , and presents normal hygrothermal 


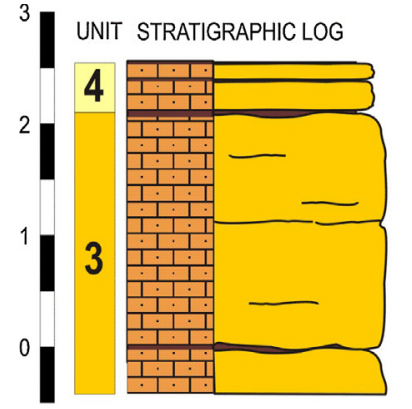

TOMB PROFILE

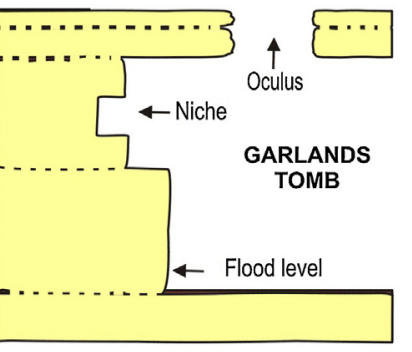

X
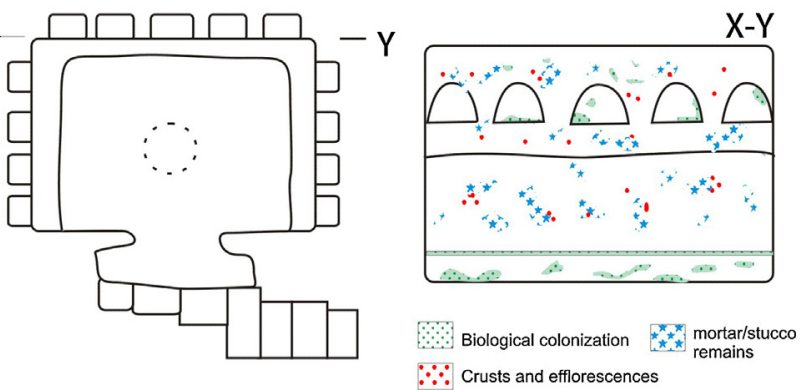

Fig. 9. Tomb of the Garlands. Lithostratigraphic column and tomb profile (top). Situation of the main deterioration types in the front wall (bottom).

conditions in relation to the exterior but longer periods and with higher values of effective condensation during the period of study (Table 2).

The tomb was carved in the Depositional Sequence II, in the massive metric-thick beds of the top of Unit 3 and the decimetric-thick lower beds of Unit 4 that constitute the roof of the tomb (Fig. 9). The rock cover is about $50 \mathrm{~cm}$, with a parterre of $0.5-1 \mathrm{~m} \mathrm{~N}$. In the summer of 2008 some works have been made outside this tomb modifying the external morphology of the area. Flooding is very frequent and the water level easily exceeds $20 \mathrm{~cm}$. The floor of the tomb is sealed by fine-grained sediments, acting as acuitard, which causes that even in the summer months the ground is saturated in water.

It is a tomb with a high degree of deterioration, in which there is no more than $60-70 \%$ mortars/stuccos on the walls and no more than $5 \%$ in the roof. It was recently restored (with restoration mortars). The deterioration features are varied and abundant, including detachment, material losses (granular disintegration), surface deposits (efflorescences, crusts) and biological colonization.

The processes of cracking, detachments and dissolution in walls and roof are abundant, accompanied by an important granular disintegration, which confers an aspect of severe deterioration to the whole tomb. The problems of mechanical stability of the roof are obvious and largely due to the thin-bedded calcarenite forming the roof of the tomb.

The surface deposits are varied:

- Accumulations of plant and animal remain on niches and ground.

- Gypsum efflorescence in walls, associated with stuccos remains, even on restored material. On one of the niches there are efflorescences composed of prismatic crystals of sodium carbonate (thermonatrite $\mathrm{Na}_{2} \mathrm{CO}_{3} \cdot \mathrm{H}_{2} \mathrm{O}$ ) and oxalate: oxammite $\left(\mathrm{NH}_{4}\right)_{2}\left(\mathrm{C}_{2} \mathrm{O}_{4}\right) \cdot \mathrm{H}_{2} \mathrm{O}$ of clear biological origin (bird guano).

- White calcitic microcrystalline crusts.

Biological colonization (mainly algae, mosses and cyanobacteria) is widespread especially considering its recent restoration. It concentrates preferably in more humid (corners of niches, hollows, and ground) and well illuminated zones (entrance, oculus walls).

\subsection{Tomb of the Three Gates}

It is a complex tomb in its morphology, with a very anthropized environment, which does not exceed $2 \mathrm{~m}$ of vertical development in its interior chambers (Fig. 10). The tomb has three sections, of which the western one has been studied, presenting better conditions of preservation and access. The tomb has an entrance stairway oriented to the $\mathrm{SW}\left(\mathrm{N} 226^{\circ}\right)$ and the entrance of the tomb is oriented to the $\mathrm{E}$, but without direct insolation. Direct flooding is provided by the stairway with sandy soil that does not appear to retain moisture for a long time, however, the tomb experienced longer periods with high values of effective condensation during the period of study (Table 2).

The tomb was carved at the upper calcarenitic beds of the lithostratigraphic unit 3 (Depositional Sequence II), as well as the adjacent Tomb of Postumius [8]. It has a cover of rock and parterre
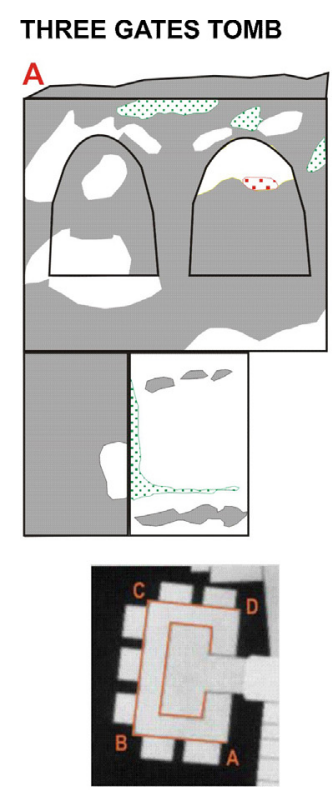
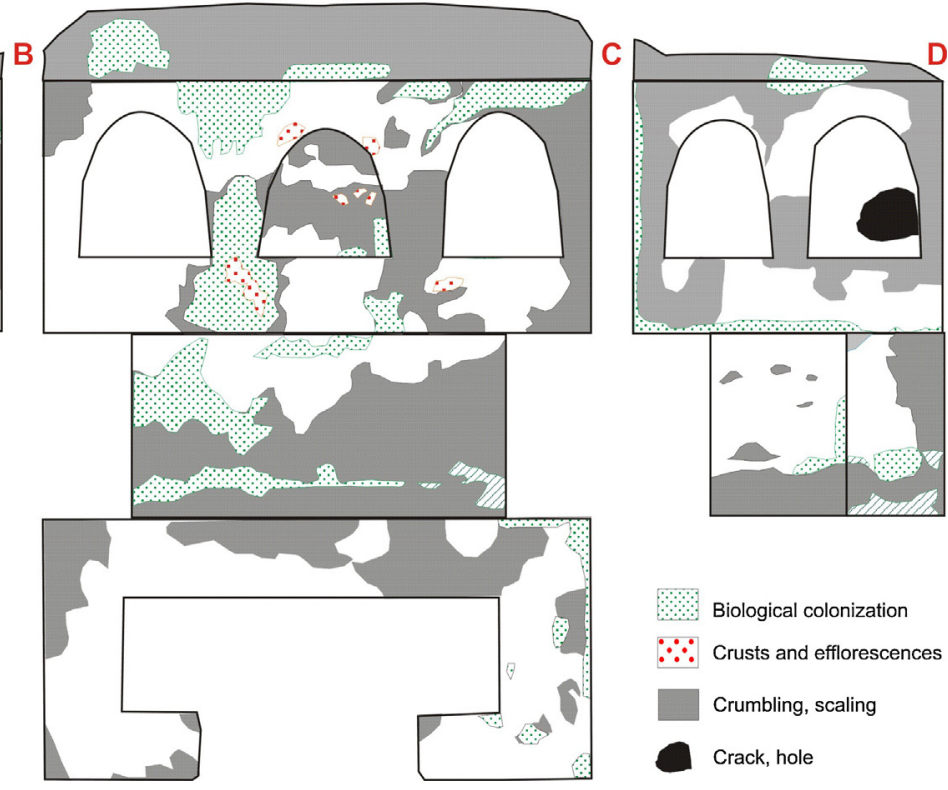

Biological colonization

$\because \because$ Crusts and efflorescences

Crumbling, scaling

Crack, hole

Fig. 10. Tomb of the Three Gates. Distribution of the main deterioration types in the tomb walls and roof. 
that exceeds $2 \mathrm{~m}$, and loose materials with a thickness of $0.7 \mathrm{~m}$. From the ground to the roof, there are $1.6-1.7 \mathrm{~m}$ height. The tomb roof is constituted by a $60 \mathrm{~cm}$-thick calcarenitic bed.

This tomb presents a severe deterioration, with abundance of collapses and loss of material but conserves part of the original stuccos that includes some paintings. The roof of the chamber is totally altered due to rock breakages, detachments and collapses. The roof collapses have been caused by mechanical instability, probably as a consequence of the weight of the overlying parterre and its capacity to retain rainwater. On the walls, the detachments are also abundant, as well as in the niches. In one of the niches there has been a collapse of the innermost wall, which has opened a hole that communicates with an adjacent room.

The deterioration features in this tomb are varied, including cracks and detachment, material losses (granular disintegration), biological colonization and, to a lesser extent, surface deposits such as efflorescences and crusts (Fig. 10). The formation of a discontinuous deposit of gypsum crystals from the micro-dissolution and its subsequent recrystallization is observed on the original decorated stuccos. Efflorescences consist of fine, white, powdery deposits with a mineralogy consisting of gypsum and calcite. Preferably they are distributed on rough (hollow) and detached surfaces. Some very fine calcitic crusts are associated with mortars.

Biological colonizations of different types are distributed throughout the tomb. Lichens dominate the stairway and, on the walls and near to the ground developed green biofilms of cyanobacteria, algae, and mosses. Direct flooding through the stairway leaves a pattern of the reached level on the walls that maintains green biofilms in the wall with northern orientation while is absent in the opposite (southern). Inside the chamber, biological colonization develops with greater intensity in the rough areas (detachments and subsequent disintegration of the host rock). In contrast, stuccos show very low biological colonization.

\section{Conclusions and recommendations}

The assessment of the deterioration processes in the tombs has allowed the establishment of the main deterioration phenomena and permits to conclude that the main deterioration agent is water. Three main mechanisms of deterioration function in the tombs:

- Cycles of condensation and evaporation with subsequent cycles of dissolution/crystallization of salts in the superficial and sub-surface porous system of the host rock, which causes disintegration by the pressure exerted by the crystallization of salts. The presence of water and its movement (capillarity) is the key factor for the development of these processes.

- Dissolution of the cement, matrix and carbonate bioclasts of the host rock, which causes the loss of cohesion and granular disintegration.

- Microbial colonization and development on biofilms on the rocks and mortars, with subsequent biodeterioration.

All these mechanisms work together over a long period of time. In fact, each tomb goes through different stages in which the decay processes vary from the moment of its construction and use, its abandonment pre- and post-burial, and its discovery/excavation to the present. Throughout this time various factors have controlled the type and intensity of decay processes that affect the Necropolis and they are natural, both intrinsic (e.g. lithology, porous system) and extrinsic (e.g. climate and effective condensation), and anthropic (modifications in the tombs and/or environment, landscaping, gardens, etc.).

Intrinsic factors such as the texture and structure (stratification planes, layering, diaclases, etc.) of the rock are also determinants in the processes of cracking and detachment, whether at the scale of chips, scales or blocks. One critical factor in the roof collapses is that many of the tombs are carved in thick massive calcarenite beds (commonly lower terms of the depositional sequences) leaving as covering rock the thinner calcarenite beds which correspond to the upper terms of the depositional sub-sequences.

A conclusive factor for the effectiveness of the deterioration mechanisms described is the difference in response of rock and mortar/stucco to environmental changes. This differential behaviour is fully controlled by the petrophysical properties of the materials which directly condition the condensation rates on the building materials.

Disintegration processes increase the exposed surface of the material, a factor that enhances other forms of deterioration, such as biological colonization. In fact, when mortar detach, the exposed rock is rapidly colonized by phototrophic microorganisms.

According to information provided by the Necropolis staff, the state of conservation of most tombs was significantly better at the time of excavation than can be observed today and the exhumation of tombs has accelerated its deterioration, provoking in a century a degree of decay greater than the one accumulated during two thousand years. In some tombs, most of the decorated mortars and stuccos were found lying on the tomb rubbles. The present state of conservation of the tombs is poor and is the result of the accumulation of different deterioration processes along the time. In many of the excavated tombs the intervention sequences after its discovery caused changes in its access and interior chamber that modified the environmental conditions leading to a high degree of humidity, condensation and marked overheating of the roof.

In addition to the works undergone in the entrances or directly inside the tombs, the modifications of their surroundings, such as the accumulation of excavation debris used for the construction of pathways and parterres all around the Necropolis, as well as the planting of trees with invasive roots, have been major factors in the acceleration of deterioration processes.

One of the main problems is that the layout of the pathways and parterres have led to a strong modification of the natural drainage network and originated strong variations in the microclimatic parameters of the interior of the tombs (e.g. Garlands, Three Gates and Four Columns tombs), and even problems of mechanical instability due to the overweight produced by the accumulated material.

From the study of the best preserved tombs, such as Tomb 118, in which there have been no significant problems of collapse or breakage of the original material, a series of favourable conditions of conservation can be extracted and summarized as:

- Very little modified setting, without presence of anthropic elements nearby.

- Rock cover of more than $1 \mathrm{~m}$ depth. The outdoor host rock has a protecting lichen cover. The roof tomb is located on a massive calcarenite bed.

- Certain insulation against external conditions (lower temperature, higher humidity and lower range of thermohygrometric oscillation), with high ventilation rates favoured by a moderatehigh winter insolation that favours the drying of the host rock. From the study it can be concluded that the high availability of water inside the tombs is the main problem for its conservation.

The analysis of the forms and mechanisms of decay and the microenvironmental ranges in which they are developed allow us to delimit microenvironmental safety thresholds under which the deterioration processes would diminish their effectiveness: 
- Relative air humidity always lowers than 65 to 85\% (depending on the season) that inhibits the effective condensation in the host rocks, minimizing the deterioration mechanisms.

- Low thermal oscillation in the interior of the tombs and that the roofs of those that are more superficial (with less rock cover) do not suffer strong insolation rates.

- Reduction of the $\mathrm{CO}_{2}$ concentration of the interior air tomb to atmospheric values (<400 ppm).

The results obtained in this study indicate that the anthropic modifications undergone by the Necropolis since its discovery and excavation are largely responsible and, in any case, catalyzing the main mechanisms of deterioration observed in the tombs. These mechanisms with different reactions and physicalchemical processes have a common factor: the presence of water in quantities and periods sufficient for activating deterioration mechanisms. Therefore, the corrective measures to be taken to minimize the effectiveness of the processes and deterioration mechanisms that currently affect the entire Necropolis should be aimed at reducing the amount of water and its time of permanence in the tombs.

Any intervention for the restoration of the interior of a tomb must be preceded by a series of previous measures that correct the origin of the deterioration problems and, therefore, the reduction of the available water in the tombs.

The proposed measures must be structured in different time and scales of work, accompanied by a monitoring of corrective measures and their influence on the tombs:

- Short-term and local measures to prevent the entry of water directly to the tombs which should include the individual protection of the entrance of each tomb to prevent the entry of water by surface runoff, the protection of stairways and oculus to prevent the entry of water by direct rainfall, but allowing ventilation, and the cleaning and adaptation of existing drainage systems. The measures for tomb protection should not cause a decrease in the rate of ventilation, as unfortunately occurred in some recent cases where a few tombs were practically closed with metal covers due to a misunderstanding of conservation proposals. The closing of these tombs caused a drastic reduction of ventilation and a sharp increase in temperature, particularly in the summer season. This favoured the processes of precipitation of carbonates on the tomb walls.

- Medium-long-term measures for the drainage restructuring at the scale of the Necropolis. Reorganization of drainages focused on the necessary modifications to redirect the water to the natural drainage areas. In the event that the reorganization of the drainage involves the total or partial removal of the pathways and parterres, the underlying rock surface must be completely exposed and cleaned of sand or similar materials and must be treated immediately afterwards. The treatment should increase its protection against weathering and reduce the intensity of rain infiltration through its porous system.

\section{Acknowledgements}

This research was funded by the Consejería de Cultura, Junta de Andalucía, the Spanish Ministry of Science and Innovation, project CGL2010-17183 and the CSIC project 201230E125. We thank the Necropolis staff for their collaboration and Mrs. Elisa Pinilla for her constant support and friendship.

\section{References}

[1] M.C. Mínguez García, M. de la Calle Vaquero, M. García Hernández, La visita en el Conjunto Arqueológico de Carmona, in: Rodriguez Temiño, I. (Coord.), Investigar, Conservar, Difundir. El Proyecto Guirnaldas en el Conjunto Arqueológico de Carmona, Universidad de Sevilla, 2014, pp. $149-170$.

[2] X. Ariño, C. Saiz-Jimenez, Deterioration of the Elephant tomb (Necropolis of Carmona, Seville, Spain), Int. Biodeterior. Biodegr. 40 (1997) 233-239.

[3] X. Ariño, M. Hernandez-Marine, C. Saiz-Jimenez, Colonization of Roman tombs by calcifying cyanobacteria, Phycologia 36 (1997) 366-373.

[4] G. Piñar, C. Saiz-Jimenez, C. Schabereiter-Gurtner, M.T. Blanco-Varela, W. Lubitz, S. Rölleke, Archaeal communities in two disparate deteriorated ancient wall paintings: detection, identification and temporal monitoring by DGGE, FEMS Microbiol. Ecol. 37 (2001) 45-54.

[5] L. Laiz, A.Z. Miller, V. Jurado, E. Akatova, S. Sanchez-Moral, J.M. Gonzalez, A. Dionísio, M.F. Macedo, C. Saiz-Jimenez, Isolation of Rubrobacter strains from biodeteriorated monuments, Naturwissenschaften 96 (2009) 71-79.

[6] M. Diaz-Herraiz, L. Laiz, V. Jurado, A.Z. Miller, J.A. Gonzalez-Perez, J.L. Santos, E. Alonso, C. Saiz-Jimenez, Analytical pyrolysis evidences the presence of granaticins in the violet stains of a Roman tomb, J. Anal. Appl. Pyrolysis 117 (2016) 357-362.

[7] I. Dominguez-Moñino, M. Diaz-Herraiz, V. Jurado, L. Laiz, A.Z. Miller, J.L. Santos, E. Alonso, C. Saiz-Jimenez, Nature and origin of the violet stains on the walls of a Roman tomb, Sci. Total Environ. 598 (2017) 889-899.

[8] D. Benavente, S. Sanchez-Moral, A. Fernandez-Cortes, J.C. Cañaveras, J. Elez, C. Saiz-Jimenez, Salt damage and microclimate in the Postumius Tomb, Roman Necropolis of Carmona, Spain, Environ. Earth Sci. 63 (2011) 1529-1543.

[9] J.C. Cañaveras, A. Fernandez-Cortes, J. Elez, S. Cuezva, V. Jurado, A.Z. Miller, M.A. Rogerio-Candelera, D. Benavente, M. Hernández-Mariné, C. Saiz-Jimenez, S. Sanchez-Moral, The deterioration of Circular Mausoleum, Roman Necropolis of Carmona, Spain, Sci. Total Environ. 518-519 (2015) 65-77.

[10] ICOMOS-ICS, Illustrated Glossary on Stone Deterioration Pattern, 2008, Available at: http://international.icomos.org/publications/monuments _and_sites/15/pdf/Monuments_and_Sites_15_ISCS_Glossary_Stone.pdf.

[11] P. Bourrelly, Les Algues d'Eau Douce. III. Algues Bleues et Rouges, Editions N. Boubée, Paris, 1970.

[12] K. Anagnostidis, J. Komárek, Modern approach to the classification system of cyanophytes. 3. Oscillatoriales, Algolog. Stud. 50-53 (1988) 327-472.

[13] M. Aboal, Aportación al conocimiento de las algas epicontinentales del sudeste de España. III. Cianofíceas (Cyanophyceae Schaffner 1909), An. Jard. Bot. Madrid 45 (1988) 3-46.

[14] L. Hoffmann, J. Komárek, J. Kastovský, System of cyanoprokaryotes (cyanobacteria) - state in 2004, Algolog. Stud. 117 (2005) 95-115.

[15] G. Clauzade, C. Roux, Likenoj de Okcidenta Europo. Ilustrita Determinlibro, Bull. Sot. Bot. Centre-Ouest, No. special 7 (1985).

[16] P.L. Nimis, M. Monte, M. Tretiach, Flora e vegetazione lichenica di aree archeologiche del Lazio, Stud. Geobot. 7 (1987) 3-161.

[17] P. Navarro-Rosinés, Els Liquens i els Fongs Liquenicoles dels Sustrats Calcaris de la Catalunya Meridional (Ph.D. thesis), University of Barcelona, 1992.

[18] D. Benavente, G. Cultrone, M. Gómez-Heras, The combined influence of mineralogy, hydric and thermal properties in the durability of porous building stones, Eur. J. Mineral. 20 (2008) 673-685.

[19] S. Sanchez-Moral, L. Luque, S. Cuezva, V. Soler, D. Benavente, L. Laiz, J.M. Gonzalez, C. Saiz-Jimenez, Deterioration of building materials in Roman catacombs: the influence of visitors, Sci. Total Environ. 349 (2005) 260-276.

[20] R.G. Allen, L.S. Pereira, D. Raes, M. Smith, Crop evapotranspiration - guidelines for computing crop water requirements, in: Irrigation and Drainage Paper No. 56, FAO, Roma, 1998.

[21] M. Hoyos, J.C. Cañaveras, S. Sánchez Moral, E. Sanz Rubio, M.T. Blanco, F. Puertas, A. Palomo, C. Sáiz Jiménez, X. Ariño, J.J. Ortega, A. Gómez Bolea, A. Canals, Estudio de los procesos de alteración de los materiales pétreos y estucos de la necrópolis de Carmona. Estudio de los procesos de alteración de los materiales pétreos y estucos de la Necropolis de Carmona, CSIC, Sevilla, 1994, unpublished report.

[22] J. Heyrman, J. Swings, 16S rDNA sequence analysis of bacterial isolates from biodeteriorated mural paintings in the Servilia Tomb (Necropolis of Carmona, Seville, Spain), Syst. Appl. Microbiol. 24 (2001) 417-422.

[23] J. Heyrman, A. Balcaen, M. Rodriguez-Diaz, N.A. Logan, J. Swings, P. de Vos, Bacillus decolorationis sp. nov., isolated from biodeteriorated parts of the mural paintings at the Servilia tomb (Roman Necropolis of Carmona, Spain) and the Saint-Catherine chapel (Castle Herberstein, Austria), Int. J. Syst. Evol. Microbiol. 53 (2003) 459-463.

[24] X. Ariño, J.J. Ortega-Calvo, A. Gomez-Bolea, C. Saiz-Jimenez, Lichen colonization of the Roman pavement of Baelo Claudia (Cádiz, Spain): biodeterioration vs bioprotection, Sci. Total Environ. 167 (1995) 353-363. 